\title{
Vers-ions con-verse: A Sequence of Translations
}

(1)

(green) spaces tending where?

or what?

this break which gives rise to syntax aspires to be skin on which is traced an other sense (a sensation)

through silence (pulses work in silence) the body learns about the outside world (your eyes your voice your hands) memory of touch where what is beyond language is inscribed while framing new fragments new ears for a new music

My knowledge of French is imperfect, so when I read French poetry I doa lot of translation into English just to make sense for myself. In this way, translation is a function of my reading. However, for the same reason, I am afraid that my translation - once it is pinned down to a particular set of choices - will always leave a record of misreadings which are more or less accidental. I say 'more or less,' because I tend to err in the direction of meanings I desire; this is embarassing.

Reading the first line of this poem, I thought about green, and also, eventually, about earthworms. I checked espace in the dictionary to make sure it was masculine, since otherwise one would hear verte. In the dictionary I found out that espace is masculine in most of its senses; however, in typography, the spaces between characters a re espaces au 
féminin; furthermore, the feminine is the older form of the word, from the Latin spatium, which is neuter. Feminine, productive space between letters and words seems relevant to Lola's poem, but when I come back to the line I write without hesitation, 'green spaces tending to what / or where?' thus sacrificing the possibility of typographical, feminine spaces in order to keep the green. However, I leave out the earthworms.

Susan Knutson

(2)

spaces lines lines leading where?

lines leading what?

this rupture opens up a syntax

insinuating into skin over which

is traced an other meaning / path (- pathy)

across silence (the pulse beats in silence)

the organism absorbs outside elements

(your eyes, voice, hands) the memory of a touch

where what is beyond language is inscribed

all the while injecting new fragments

new ears for a new music

To be able to write and live in two languages as Lola does must beexhilarating, but also bewildering. For some things must be said in French, others in English. But what are they? And the translator of Lola's poems from French into English is in a precarious position, because she thinks of how Lola might have said this in English herself and why she chose to do so in French. Watching Lola turn from English to French and back again as she does in 'sophie, seeking out her very own langue, is intriguing. For I found a marked difference between the poems in French and English as if another kind of sensibility were speaking, and I wondered how much that was a consequence of the 
French language itself. The vers in French were more constrained, less layered, and the voice emerging was more subdued, less colloquial. It is then that the translator becomes very curious to know how the language Lola writes in determines what she says and how she says it, and she sets down to her task with several voices echoing in her head.

Well now how to tackle the poem as it lies there so pristine and perfect and unsuspecting in French? Mixture of anticipation and reluctance. Take up my pen, open my dictionary, scribble down a literal transcription, which even as I write falls victim to crossings over, erasures, insertions. Recreate this incoherence onto my computer. Then go away for a day or two to assess the poem's readability in English.

I think it was Barbara who once said that feminist texts (or highly experimental ones) seem to require quite literal translations. That, or quite free ones. Lola's poems, as do Nicole Brossard's texts, invite this literal rendering so that when Gail translates 'qui se veut peau sur laquelle se trace un autre sens (une sensation)' quite literally as 'which wishes itself skin on which meaning is traced' over the phone to me, it possesses both fidelity and eloquence (I can hear the French and Lola's voice), but I change it to: 'insinuating into skin over which ...' I can't help myself but my voice insinuates itself into Lola's. I am not quite happy about this. I fall here towards 'very free.' And again when there are polysemous puns as in 'vers' (towards, lines of verse, worms, [green]) I leave out the worms, [green] and instead there are lines leading' into only a couple of possible meanings. Add, shift (verbs, adjectives) omit (gender 'laquelle'; the self-reflexivity of verbs 'se trace' and 's' inscrit'; the finality of nouvelle, as it stands feminine, solitary, the poem's closure) and apprehensively watch the reader (and Lola) reading this new poem.

\section{Kathy Mezei}

(3)

spaces lines lead where?

verse what?

this break which gives place to syntax would-be skin on which is traced an 
other direction / sense (a sensation)

through silence (pulses throb in silence)

the body enquires about external elements

(your eyes your voice your hands) memory of touch

the beyond of a tongue inscribed inserting

new parts new ears for a new

music

Commentary as extension of the reading:

like deferred fate those lines (in the skin dimly traced) other senses arise as alternate routes (a sixth in language more than cube?), chords of meaning found in palimpsest, the palimpsest the break (in sense) allows to surface on the page in silence in between its versions: echo scan in green depths.

in translating a poem that so intensively works the language it seems already a translation of that original struggle between intent and language drift, the translation (becomes) process embeds metatranslation while the target language not wanting to replace / consume the resonance of the source language oscillates in potential conversation with it.

the experience of simultaneity cross-echo scanned between two languages in working with a poet who writes very much inside of both, even in other poems together.

through several drafts (drifts?) the sense that French wants to spell out the syntax in a gracious offering of connection that lumbers clumsily demanding into literal English, while a 'freer' English tends to make it resonate all at once although it is always leading somewhere just as French does. a genius for elucidation (abstract words affiliate easily); a genius for compression (touch and touching upon); an oscillation between the two.

Daphne Marlatt 
(4)

spaces vers-ions con-verse?

in-verse?

this rupture makes way for a syntax

wanting to be skin on which is traced an

other sense (a sensation)

traversing silence (the pulses work in silence)

the organism inquires about external elements

(your eyes your voice your hands) the memory of a touch

where the far side of language is inscribed while inserting

new fragments new ears for a new

music

This was a difficult translation. I resisted setting to work on it. Translation holds out the illicit pleasures of language. But I wanted to take the risk of ideas and leave language to its own games. That first line was a problem. All the puns on 'vers' - verse, green, worm, towards. In one word they compress the interlocking issues of the poem; new directions, new poetry from a different body. How could I choose only one of these when the mind is enticed into the poem by the complex palimpsest of 'vers'? How, if I settled for one of these meanings, could I retain the repetition of 'vers' in the next two phrases, and in theopening word of the third section, leitmotif that holds the poem together in the ear, making that new music for the new organs of hearing?

Verbal music is important in this poem about the music of poetry. Sound teases out the sense: the ear leads the mind in new directions. To retain this music for the allegory, with lute in her hand, on the cover of 'sophie is important. For the major issue tackled in this book is the problem of the insertion of the feminine into the discourse of philosophy. The book is a critique of the logocentrism of the Western tradition. Suffering from a Platonic hangover, this discouse has been dominated by metaphysics. The consequent opposition between the intelligible and the sensible, has privileged mind over body, male over female. For this discourse has been a discourse between men in which 
woman has been the sign or token of exchange. If we are to put Sophie back into the discourse alongside Phil, as Lola Lemire Tostevin is trying to, we are going to have to develop our ears, as indeed all of our organs, to accommodate ourselves to a new type of knowledge. This rupture, the word disclosing yet simultaneously purifying from the 'abject,' is music: 'A single catharsis: the rhetoric of the pure signifier, of music in letters ...**

So, rather than choose, I did nothing. But the problem did not go away. On the telephone with a colleague about a theoretical paper on translation, our conversation touched on a series of words that shared a root with the German word for translation; inversion, perversion, conversion, subversion. English words for movement, these contain both 'turning' and 'verses.' My Oxford dictionary informs me too that 'vert' is an English word for the right to cut all the greenery in the forest. Three of the meanings can be suggested if I can retain the syllable 'ver.' For a while, I toyed with using thearchaic 'verdant' or 'versatile' to provide more variety in the repetitions of the sound. But these signifiers set up semantic chains that led in diverging directions. Several weeks later in the swimming pool, I am thinking about Lola's book, about how I must phone her to see if she knows where the reading will take place and if she can bring copies of her book to sell to the students who need them. Suddenly, into my mind rushes the word 'vers-ions' complete with hyphen in the middle (or should it be a slash?). Meditation and water are forever wedded, wrote Melville in Moby Dick. To underline the musical theme, and as homage to Barry Nichol whom both Lola and I miss, I thought of adding the word 'organ' before music in the final line. However, 'organism' in the same section of the poem is a much more subtle form of quotation of Organ Music, more in keeping with the economy of the poem. And so, in place of the apostrophe of the title, which stands for the blank pauseas the conceptual space of the feminine in the discourse of philosophy, the translation should read: 'water music: themeand vers-if-ications.'

\section{Barbara Godard}

\footnotetext{
* Julia Kristeva, Powers of Horror: An Essay on Abjection, trans. Leon S. Roudiez (New York: Columbia, 1982), 23.
} 
(5)

green spaces / spacing where?

spacing what?

this broken surface which opens syntax

like skin tingling under the trace of

new sense (sensation)

across silence (an electric charge is noiselessly propulsed)

the organism lights its place by what's outside

(your eyes your voice your hands) the memory of a touch

a tongue slipping into space beyond language lapping

new fragments new ears for new

music

Lola's writing has the clarity and theoretical rigour one connects with la modernité in Québec. And a way of using the poetic line, a concreteness about her images as well, which evokes English-Canadian poetry for me. People often say I write between two languages. Lola does more so. Her knowledge of French lightens, enlightens the English in which she often writes. Or, if writing in French, her writing somehow floats, imbued with the wisdom of apprehending the language from within (as mother-tongue), yet also through eyes that know English profoundly. This gives it a quality which is, strangely, both material (full of concrete meaning) and immaterial (curving away from the horizon of meaning).

If, in general, translation is not so much transparent as it is evidence of another reading - this is even truer of the translation of a text which, in its writing, already anticipates the other language (i.e. English). My translation is very much influenced by my own preoccupation with space as a conduit across which a writing subject in-the-feminine is constantly in a process of becoming. ${ }^{*}$ No doubt this preoccupation has forced an emphasis, in the translation, on the concept of spaceand the

* This is a major theme of my 'essays' in Spaces Like Stairs (Toronto: Women's Press, 1989). 
Vers-ions con-verse: A Sequence of Translations · 23

movement across it of the trace that is writing. A space electrified at the point where theory and the erotic touch. Electrified more, oddly enough, in English - where the discussion of either the erotic or of theory seem somehow more unusual (therefore more marked) when inserted in the text. In French the erotic and the theoretical seem to come comfortably together, here, in the same phrase. In English there's a distance between the two 'concepts' which obliged me, in the process of translation, to lean towards one or the other-a choice made almost unconsciously in the beginning, but which became clear to me with the line

où s'inscrit l'au-delà d'une langue tout en insérant.

I might have taken a more clearly theoretical tack:

where is inscribed what's beyond language inclusive of but I chose the more erotic, the more electric version a tongue slipping into space beyond language lapping it seemed the most poetic way ... in English.

Gail Scott 